\title{
Article \\ Different Green Manures (Vicia villosa and Brassica juncea) Construct Different Fungal Structures, Including Plant-Growth-Promoting Effects, after Incorporation into the Soil
}

\author{
Waleed Asghar and Ryota Kataoka *
}

check for

updates

Citation: Asghar, W.; Kataoka, R. Different Green Manures (Vicia villosa and Brassica juncea) Construct Different Fungal Structures, Including Plant-Growth-Promoting Effects, after Incorporation into the Soil. Agronomy 2022, 12, 323. https://doi.org/10.3390/agronomy 12020323

Academic Editors: Helena Freitas and Rui S. Oliveira

Received: 5 January 2022

Accepted: 24 January 2022

Published: 26 January 2022

Publisher's Note: MDPI stays neutral with regard to jurisdictional claims in published maps and institutional affiliations.

Copyright: (C) 2022 by the authors. Licensee MDPI, Basel, Switzerland. This article is an open access article distributed under the terms and conditions of the Creative Commons Attribution (CC BY) license (https:// creativecommons.org/licenses/by/ $4.0 /)$.
Department of Environmental Sciences, Faculty of Life and Environmental Sciences, University of Yamanashi, Kofu 400-8510, Japan; waleedasghar978@gmail.com

* Correspondence: rkataoka@yamanashi.ac.jp

\begin{abstract}
The application of green manure to soil improves soil health by increasing biological activity. However, little attention has been paid to the effects of different green manures on the microbiological community and soil function after incorporation. Here, it was found that the green manures of Vicia villosa (leguminous) and Brassica juncea (non-leguminous) have different fungal structures, despite the soil originally being the same. Moreover, some isolated strains showed plant-growth-promoting abilities. Three strains (H1: Penicillium spp., H2: Clonostachys spp., and H3: Trichoderma spp.) from leguminous-manure-incorporated soil and four strains (B1: Purpureocillium spp., B4: Taifanglania spp., B6: Trichoderma spp., and B10: Aspergillus spp.) from non-leguminous-manure-incorporated soil showed the potential for plant growth enhancement. Plant-growth-promoting traits revealed that four strains possessed phosphate solubilization and siderophore production, although none of them showed the ability to produce indole-3-acetic acid (IAA)-like compounds with/without tryptophan. In addition, higher extracellular enzyme activities_including endoglucanase and $\beta$-glucosidase activities-were also detected in the soil-incorporated green manures. In conclusion, this study suggests that different fungal structures appeared when different green manures were applied, which promoted plant growth. This indicates the potential benefits of promoting the incorporation of green manure into the soil.
\end{abstract}

Keywords: green manure; fungal structure; plant-growth-promoting fungi; plant-growth-promoting traits

\section{Introduction}

The use of mineral fertilizers in agriculture increases crop yields but decreases soil quality and microbial populations [1,2]. Environmental concerns, stemming from the use of mineral fertilizers on the one hand, and the availability of these fertilizers-especially phosphorus- and nitrogen-based fertilizers - on the other hand, are vital issues in current agriculture [3]. Crop nutrition requirements can alternatively be met by organic fertilizers, including animal- or plant-based organic residues [4]. Issues with the use of organic fertilizers include slow release, bulkiness, the spread of weeds, and non-uniform composition [5]. Therefore, a sustainable solution and new alternative technologies are being developed to replace mineral and slow-release fertilizers, in order to reduce environmental problems and improve crop productivity and soil health.

The incorporation of green manure can affect soil microbial communities directly and indirectly, by providing the nutrients to the soil and plants, and also leads to changes in the soil's nutrient status [6,7]. Green manures can influence soil microbial diversity through the release of root exudates [8]. There is a paucity of information on the effects of different green manures on microbial groups and how they increase microbial activity-especially in rice-cropping systems [8,9]. The changes in soil microbial composition following green 
manure amendment can provide more enzymes that regulate nutrient fluxes, leading to the promotion of plant growth $[10,11]$. The extent of changes may depend on the quantity and type of green manure added $[10,12]$. Common plant species used for green manure include Chinese milk vetch, barley, red clover, and mustard oats, and they can be leguminous or nonleguminous plants [13]. Recent studies using high-throughput sequence analysis showed that green manure could change the soil microbial community structure $[9,11]$. In particular, the behavior of various fungal community structures at the molecular level, affected by the introduction of leguminous and non-leguminous green manure in soil systems, leads to the promotion of plant growth. Although soil fungal communities play a crucial role in soil ecosystems' functioning by decomposing organic matter, influencing nutrient cycling, and promoting plant growth [14], little is yet known on this subject. Therefore, monitoring of the fungal community structure after incorporation of green manure is very important. However, there is still little information on the effects of different types of green manure, such as Vicia villosa-commonly called "hairy vetch" (leguminous)—and Brassica juncea (non-leguminous), on soil fungi and soil enzyme activities.

Plant-growth-promoting microorganisms (PGPMs) are widely accepted to enhance crop production, and can be used to meet the ever-increasing food demand [15,16]. PGPMs, such as fungi and rhizobacteria, enhance plant growth and development through different functions, such as production of plant hormones, enhancing nutrient availability [17,18], and production of volatile organic compounds $[19,20]$. Many plant-growth-promoting fungi (PGPF) are known to produce siderophores, improving the iron nutrition of plants under an iron-depleted environment [21]. Additionally, many PGPF have been found not only to be non-pathogenic, but also to induce resistance against pathogenic infections [22]; they also help to increase nutrient uptake from the soil as needed [16]. This may directly or indirectly promote plant growth. Therefore, the consistent use of PGPMs could lead to the replacement of mineral fertilizers and pesticides. Numerous studies have explored fungal characteristics in terms of plant-growth-promoting traits $[16,19,22]$, but the characteristics of PGPF in the soil after the incorporation of green manure have not yet been explored. In this regard, it was assumed that incorporating different green manures could lead to different fungal structures and influence plant growth through their promotion effects. Thus, keeping in mind that this study was conducted to isolate the fungal strains from the soil after incorporation of green manure ( $V$. villosa (hairy vetch) and B. juncea), plant-growthpromoting ability was evaluated to determine their effects on the growth of two different vegetable crops: Brassica rapa var. perviridis and Lactuca sativa var. crispa-commonly called komatsuna and lettuce, respectively.

\section{Materials and Methods}

\subsection{Isolation of Fungi}

Hairy vetch (Vicia villosa) and Brassica juncea were selected based on commonly cultivated green manures in japan. Brassica juncea (TAKII Co., Ltd., Kyoto, Japan) and hairy vetch ((SNOW BRAND SEED Co., Ltd., Hokkaido, Japan) seeds were obtained commercially. Vicia villosa (leguminous) and Brassica juncea (non-leguminous) as green manures were grown in $300 \mathrm{~g}$ of soil contained in Neubauer pots $\left(100 \mathrm{~cm}^{2}\right.$ volume; Fujiwara Seisakusho, Ltd. Tokyo, Japan) for five weeks (flowering stage) under controlled climate conditions (temperature: $25^{\circ} \mathrm{C}, 18 \mathrm{~h}$ day, $6 \mathrm{~h}$ night). Five replicated pots were established for each treatment, and no organic or chemical fertilizers were added to the green manure treatment pots. After that, $15 \mathrm{~g}$ of Vicia villosa and $15 \mathrm{~g}$ of Brassica juncea green manures were incorporated into the soil, and soil samples were collected after two months of the incorporation of green manures. Samples were carefully shaken to separate the plant roots and stones, and were stored at $4{ }^{\circ} \mathrm{C}$ until fungal isolation.

Fungi were isolated from both samples $(0.5 \mathrm{~g})$ by serial dilution plating on Martin agar plates [23]. Soil $(0.5 \mathrm{~g})$ was added to $5 \mathrm{~mL}$ of sterile distilled water (SDW), mixed using a vortex mixer, and serially diluted. Then, $50 \mu \mathrm{L}$ was taken from each suspension $\left(10^{-2}, 10^{-3}\right.$, and $10^{-4}$ ), spread onto Martin agar plates, and incubated for one week at $25^{\circ} \mathrm{C}$. After the 
appearance of the fungal colonies, each colony was selected based on visual morphology and re-streaked on potato dextrose agar plates until a single pure colony type per plate was achieved.

\subsection{DNA Extraction and PCR Amplification for Isolated Fungi}

DNA was extracted from the isolated fungal strains using the ZR bacterial/fungal DNA MiniPrep Kit ${ }^{\mathrm{TM}}$ (Zymo Research Corp., Irvine, CA, USA). The internal transcribed spacer (ITS) region of rDNA was used to identify isolated strains. DNA extracted from the isolated strains was mixed before PCR amplification. The universal primers ITS1 (5'-TCCGTAGGTGAACCTGCGG-3') and ITS4 (5'-TCCTCCGCTTATTGATATGC- $\left.3^{\prime}\right)$ were used to amplify the ITS region on a TaKaRa PCR Thermal Cycler Dice ${ }^{\circledR}$ Series Gradient (Takara, Shiga, Japan). The PCR amplification conditions were as follows: $95^{\circ} \mathrm{C}$ for $5 \mathrm{~min}$, followed by 30 cycles of $94{ }^{\circ} \mathrm{C}$ for $30 \mathrm{~s}, 5{ }^{\circ} \mathrm{C}$ for $30 \mathrm{~s}$, and $72{ }^{\circ} \mathrm{C}$ for $1 \mathrm{~min}$, followed by a final extension at $72{ }^{\circ} \mathrm{C}$ for $7 \mathrm{~min}$. The amplification mixture for PCR (total volume: $25 \mu \mathrm{L}$ ) contained $12.5 \mu \mathrm{L}$ of GoTaq Green Master Mix (Promega, Madison, WI, USA), $9.5 \mu \mathrm{L}$ of sterilized distilled water, $1 \mu \mathrm{L}$ of DNA template, and $1 \mu \mathrm{L}$ of each primer. The amplification products $(5 \mu \mathrm{L})$ were subjected to electrophoresis on a $1 \%(w / v)$ agarose gel in Tris-acetate-ethylenediaminetetraacetic acid buffer at $100 \mathrm{~V}$ for $25 \mathrm{~min}$ and visualized by GelRed ${ }^{\mathrm{TM}}$ staining (1:20,000 dilution; Biotium, Fremont, CA, USA) [4]. The obtained DNA sequences were compared with those previously reported in the DNA Data Bank of Japan (http:/ / blast.ddbj.nig.ac.jp/, accessed on 5 May 2021), and closely related species were noted. Molecular Evolutionary Genetics Analysis (MEGA) software was used for phylogenetic analysis [24]. The sequences corresponding to the identified isolates were then submitted to the DNA Data Bank of Japan (DDBJ) for accession numbers.

\subsection{Screening of Plant-Growth-Promoting Fungi (PGPF)}

\subsubsection{Microcosm Experiment under Axenic Conditions}

For screening PGPF, 22 out of 42 fungal strains detected in soil incorporated with hairy vetch and $B$. juncea were isolated based on visual morphology and ITS region sequencing. Brassica rapa var. perviridis and L. sativa var. crispa (lettuce) were grown in lidded polypropylene tubes (exterior dimensions: $4 \mathrm{~cm} \times 11 \mathrm{~cm}$, volume: $120 \mathrm{~mL}$ ) filled with $100 \mathrm{~g}$ (dry weight) of sterilized soil ( $1 \mathrm{~h}$ autoclave at $121^{\circ} \mathrm{C}$ ). Soil moisture was maintained at $60 \%$ water-holding capacity. Mycelia of each fungal strain, grown in $5 \mathrm{~mL}$ of potato dextrose broth (PDB) media under incubation at $25^{\circ} \mathrm{C}$ for 7 days, were transferred to the pots. No fungal mycelium was added to the control pot (CK). Pre-germinated seeds of $B$. rapa and L. sativa were transferred to pots, which were placed in a growth chamber (temperature: $25^{\circ} \mathrm{C}$; photoperiod: $16 \mathrm{~h}$ day, $8 \mathrm{~h}$ night). The experiment continued for five weeks, and plant shoot and root biomass were measured. Seven strains (H1, H2, and H3 from hairy vetch- and B1, B4, B6, and B10 from B. juncea-incorporated soil) were selected for further analysis based on fresh weights of roots and shoots. This experiment was conducted with one replication because of pre-screening for further experiments.

\subsubsection{Microcosm Experiment under Non-Axenic Conditions}

Another plant growth experiment was conducted on a larger scale to further assess the effects of the seven selected strains after PGPF screening. A total of 80 Neubauer pots were filled with $300 \mathrm{~g}$ of air-dried soil (containing $190 \mathrm{mg} \mathrm{kg}^{-1}$ available phosphate and $23.1 \mathrm{mg} \mathrm{kg}^{-1}$ nitrate-N; not sterilized) and placed in a climate-controlled room (temperature: $2{ }^{\circ} \mathrm{C}$; photoperiod: $18 \mathrm{~h}$ day, $6 \mathrm{~h}$ night). A suspension of selected strain media, with conditions similar to those followed while making axenic cultures, was transferred to the pots. The same volume $(5 \mathrm{~mL})$ of fungal-free PDB medium was used as the control (CK). The pots were covered with aluminum foil for one week to stabilize microbial activity. Pre-germinated seeds of $B$. rapa and L. sativa were transplanted to the pots, and plants were grown for 35 days with 5 replicates per treatment. Soil moisture was maintained at 
$60 \%$ water-holding capacity and monitored daily. B. rapa and L. sativa were harvested after 35 days, and shoot and root biomass were determined.

\subsection{Characterization of Selected Strains}

\subsubsection{Plant-Growth-Promoting Traits of Isolated Fungi}

To investigate the ability of $P$ solubilization in the seven selected strains, we used the medium described by Pikovskaya [25]. Each strain was grown on the medium in triplicate and incubated at $25{ }^{\circ} \mathrm{C}$ for 7 days. Clear zones around the selected strain colonies were proof of $\mathrm{P}$ solubilization, and the results were compiled using the following index: $(+)$ clear zone, $(-)$ no clear zone, and $( \pm)$ detectable but not apparent zone.

The determination of siderophore production by selected strains was carried out using a slightly modified chrome azurol S (CAS) method [26,27]. Selected strains were grown on potato dextrose agar medium in triplicate and incubated for $24 \mathrm{~h}$, and then covered with $10 \mathrm{~mL}$ of CAS medium containing the following elements: $6.04 \mathrm{mg}$ of CAS, $7.3 \mathrm{mg}$ of hexadecyltrimethylammonium bromide, $3.04 \mathrm{~g}$ of piperazine-1,4-bis(2-ethanesulfonic acid), and $1 \mathrm{~mL}$ of $1 \mathrm{mM} \mathrm{FeCl} 3 \cdot 6 \mathrm{H}_{2} \mathrm{O}$. After pouring the medium, the plates were incubated at $25{ }^{\circ} \mathrm{C}$ for 7 days. The color of the CAS medium changed from blue to yellow or orange, indicating siderophore production. The results were compiled using the following index: $(+)$ color change, $(-)$ no color change, and $(++)$ color change throughout the medium.

Isolated strains were tested for indole-3-acetic acid (IAA)-like compound production. PDB medium $(20 \mathrm{~mL})$ was added to $50 \mathrm{~mL}$ falcon tubes. Each strain was grown in the medium in triplicate and incubated at $25^{\circ} \mathrm{C}$ for 7 days with and without $1 \mathrm{mM}$ and $60 \mathrm{mM}$ (final concentration) tryptophan. After 7 days of incubation, the medium was collected and centrifuged at $10,000 \times g$ for $10 \mathrm{~min}$. Next, $1.2 \mathrm{~mL}$ of Salkowski reagent [28,29] was mixed with $300 \mu \mathrm{L}$ of supernatant. A spectrophotometer was used to assess the presence or absence of a pink color at $535 \mathrm{~nm}$.

\subsubsection{Extracellular Enzyme Activities of Isolates}

A carboxymethyl cellulose plate assay was performed to detect endoglucanase activity [30]. Briefly, the assay used $1 \% \mathrm{CMC}$ mixture, $15 \mathrm{~g} \mathrm{~L}^{-1}$ agar, $2.0 \mathrm{~g} \mathrm{~L}^{-1} \mathrm{~K}_{2} \mathrm{HPO}_{4}$, $7.0 \mathrm{~g} \mathrm{~L}^{-1} \mathrm{KH}_{2} \mathrm{PO}_{4}, 10 \mathrm{~g} \mathrm{~L}^{-1}\left(\mathrm{NH}_{4}\right)_{2} \mathrm{SO}_{4}, 0.1 \mathrm{~g} \mathrm{~L}^{-1} \mathrm{MgSO}_{4} 7 \mathrm{H}_{2} \mathrm{O}, 0.6 \mathrm{~g} \mathrm{~L}^{-1}$ yeast extract, and $10 \mathrm{~g} \mathrm{~L}^{-1}$ microcrystalline cellulose. The plates were filled with medium, and isolated strains were grown in triplicate; they were incubated for 4 days at $30^{\circ} \mathrm{C}$, and growth was monitored. Next, $10 \mathrm{~mL}$ of $0.1 \%$ Congo red dye was flooded on the medium and stained for $30 \mathrm{~min}$. The medium's surface was then washed with $5 \mathrm{~mL}$ of $0.5 \mathrm{M} \mathrm{NaCl}$ for $10 \mathrm{~min}$, and the results were compiled by the appearance of a pale yellow halo zone surrounding the isolated strain colonies. The results were compiled using the following index: $(+)$ clear zone, $(-)$ no clear zone detectable.

$\beta$-Glucosidase activity was estimated using a pure culture of isolated strains in triplicate [31]. Samples (0.5 mL each) were taken from each isolated strain, centrifuged at $10,000 \times g$ for $10 \mathrm{~min}$, and transferred into $15 \mathrm{~mL}$ conical tubes; $1.5 \mathrm{~mL}$ of buffer solution (containing $0.2 \mathrm{M}$ sodium hydrogen phosphate and $0.1 \mathrm{M}$ citric acid, $\mathrm{pH} 4.9$, for $\beta$-glucosidase), $0.9 \mathrm{~mL}$ of distilled water, $0.1 \mathrm{~mL}$ of toluene, and $0.6 \mathrm{~mL}$ of $50 \mathrm{mM}$ $p$-nitrophenyl- $\beta$-D-glucopyranoside monohydrate solution were then added into the tubes. The tubes were shaken vigorously for $30 \mathrm{~s}$ and incubated at $35^{\circ} \mathrm{C}$ for $1 \mathrm{~h}$. After incubation, $8 \mathrm{~mL}$ of ethanol was added to each tube and shaken again. Next, $2 \mathrm{~mL}$ of $2 \mathrm{M}$ Tris buffer was mixed with $1 \mathrm{~mL}$ of suspension, and absorbance was assessed using a spectrophotometer at $400 \mathrm{~nm}$. A standard curve was prepared with concentrations of $0,20,50$, and $200 \mu \mathrm{M}$ of $p$-nitrophenol solutions. A similar procedure was carried out to prepare the control tubes to compensate for any background unrelated to $p$-nitrophenol released by $\beta$-glucosidase activity. 


\subsection{Statistical Analysis}

Dunnett's test was conducted for multiple comparisons of plant growth parameters in the pot experiments.

\section{Results}

\subsection{Isolation and Identification of Fungi}

The abundance of total fungal biomass was assessed based on the number of colonyforming units (CFUs). The fungal biomass was higher in the hairy-vetch-incorporated soil at $2.98 \times 10^{6} \mathrm{CFU} \mathrm{g}^{-1}$ of soil, whereas it was $1.14 \times 10^{6} \mathrm{CFU} \mathrm{g}^{-1}$ in B. juncea-incorporated soil (Table S1). A total of 42 fungal strains were isolated and selected from both types of green-manure-incorporated soil, based on visual morphology and ITS region sequencing. The fungal isolates from the hairy-vetch-incorporated soil belonged to various genera, including Penicillium, Clonostachys, Trichoderma, Talaromyces, Colletotrichum, Mucor, Cunninghamella, Metarhizium, Pseudogymnoascus, Didymella, Fusarium, and Myrothecium. The genera Purpureocillium, Stachybotrys, Mucor, Taifanglania, Trichoderma, Aspergillus, Fusarium, Monocillium, and Humicola were identified in the B. juncea-incorporated soil. It was observed that the genera Penicillium, Talaromyces, and Trichoderma were the most dominant in the hairy-vetch-incorporated soil, while the genera Mucor, Taifanglania, and Trichoderma were the most dominant in the B. juncea-incorporated soil (Figure 1a,b). The accession numbers of the isolated fungal strains are listed in Table $1 \mathrm{a}, \mathrm{b}$.

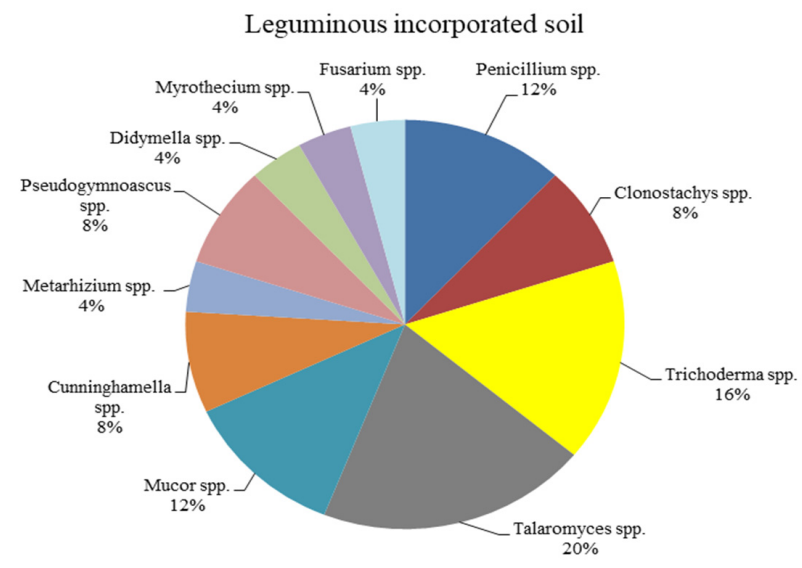

(a)

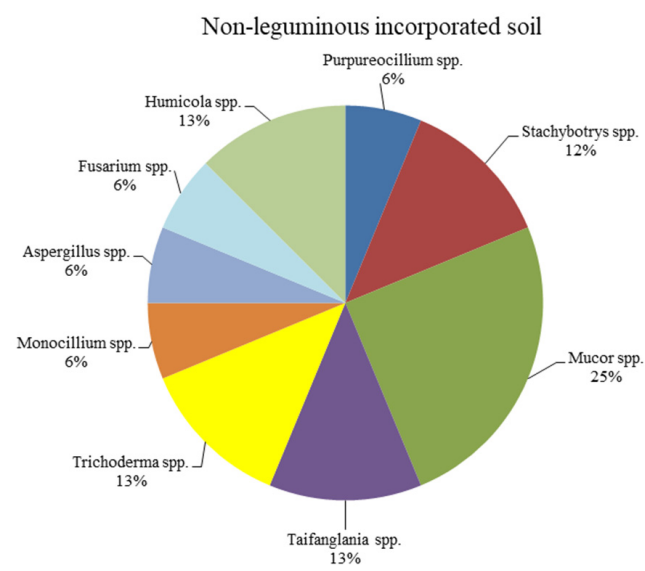

(b)

Figure 1. (a) Twenty-five strains isolated from leguminous-manure-incorporated soil, where the dominant genera were Penicillium, Talaromyces, and Trichoderma; (b) seventeen strains isolated from non-leguminous-manure-incorporated soil, where the dominant genera were Mucor, Taifanglania, and Trichoderma. 
Table 1. (a) List of the fungi isolated from the soil incorporated with leguminous plant soil. (b) List of the fungi isolated from the soil incorporated with non-leguminous plant soil.

\begin{tabular}{|c|c|c|c|}
\hline \multicolumn{4}{|c|}{ (a) } \\
\hline Leguminous Soil & Blast Closest Match & Identity & Accession Number \\
\hline H1 & $\begin{array}{c}\text { Penicillium brasilianum } \\
\text { (KY701767) }\end{array}$ & $421 / 424(99 \%)$ & LC638643 \\
\hline $\mathrm{H} 2$ & $\begin{array}{c}\text { Clonostachys rosea } \\
\text { (KY810798) }\end{array}$ & $495 / 495(100 \%)$ & LC638644 \\
\hline $\mathrm{H} 3$ & $\begin{array}{l}\text { Trichoderma harzianum } \\
\text { (KY552264) }\end{array}$ & $555 / 555(100 \%)$ & LC638645 \\
\hline $\mathrm{H} 4$ & $\begin{array}{c}\text { Talaromyces pinophilus } \\
\text { (MF68681) }\end{array}$ & $515 / 516(99 \%)$ & LC638646 \\
\hline H5 & $\begin{array}{c}\text { Talaromyces adpressus } \\
\text { (KY425714) } \\
\text { Trichoderma }\end{array}$ & $498 / 499$ (99\%) & LC638647 \\
\hline H6 & $\begin{array}{l}\text { tomentosum } \\
\text { (KC576650) } \\
\text { Trichoderma }\end{array}$ & $539 / 540(99 \%)$ & LC638648 \\
\hline $\mathrm{H} 7$ & $\begin{array}{l}\text { tomentosum } \\
\text { (FJ412070) }\end{array}$ & $557 / 558(99 \%)$ & LC638649 \\
\hline H8 & $\begin{array}{l}\text { Penicillium brasilianum } \\
\text { (MH857470) }\end{array}$ & $513 / 513(100 \%)$ & LC638650 \\
\hline H9 & $\begin{array}{c}\text { Penicillium brasilianum } \\
\text { (MH857470) } \\
\text { Trichoderma }\end{array}$ & $508 / 508(100 \%)$ & LC638651 \\
\hline $\mathrm{H} 10$ & $\begin{array}{c}\text { tomentosum } \\
\text { (FJ412070) }\end{array}$ & $547 / 548(99 \%)$ & LC638652 \\
\hline H11 & $\begin{array}{l}\text { Colletotrichum rosea } \\
\text { (MK075014). }\end{array}$ & $494 / 494(100 \%)$ & LC638653 \\
\hline $\mathrm{H} 12$ & $\begin{array}{l}\text { Mucor circinelloides } \\
\text { (KR709187) }\end{array}$ & $563 / 563(100 \%)$ & LC638654 \\
\hline H13 & $\begin{array}{l}\text { Mucor circinelloides } \\
\text { (MN105451) }\end{array}$ & $574 / 574(100 \%)$ & LC638655 \\
\hline H14 & $\begin{array}{c}\text { Cunninghamella } \\
\text { bertholletiae } \\
\text { (JN205877) }\end{array}$ & $691 / 696(99 \%)$ & LC638656 \\
\hline H15 & $\begin{array}{l}\text { Cunninghamella } \\
\text { bertholletiae } \\
\text { (JN205877) }\end{array}$ & $689 / 700(985)$ & LC638656 \\
\hline H16 & $\begin{array}{l}\text { Mucor circinelloides } \\
\text { (MW577264) } \\
\text { Metarhizium }\end{array}$ & $689 / 700(98 \%)$ & LC638658 \\
\hline H17 & $\begin{array}{c}\text { marquandii } \\
\text { (MK952275) }\end{array}$ & $579 / 579(100 \%)$ & LC638659 \\
\hline H18 & $\begin{array}{c}\text { Pseudogymnoascus } \\
\text { pannorum } \\
\text { (MH864862) }\end{array}$ & $505 / 505(100 \%)$ & LC638660 \\
\hline H19 & $\begin{array}{l}\text { Fusarium oxysporum } \\
\text { (MW563929) }\end{array}$ & $487 / 487(100 \%)$ & LC638661 \\
\hline $\mathrm{H} 20$ & $\begin{array}{l}\text { Didymella americana } \\
\text { (KY099740) }\end{array}$ & $478 / 478(100 \%)$ & LC638662 \\
\hline $\mathrm{H} 21$ & $\begin{array}{l}\text { Talaromyces sp. } \\
\text { (MW670552) }\end{array}$ & $479 / 479(100 \%)$ & LC638663 \\
\hline $\mathrm{H} 22$ & $\begin{array}{l}\text { Talaromyces pinophilus } \\
\text { (MW363693) }\end{array}$ & $502 / 502(100 \%)$ & LC638664 \\
\hline $\mathrm{H} 23$ & $\begin{array}{l}\text { Myrothecium sp. } \\
\text { (MK775959) }\end{array}$ & $513 / 513(100 \%)$ & LC638665 \\
\hline $\mathrm{H} 24$ & $\begin{array}{c}\text { Pseudogymnoascus } \\
\text { pannorum } \\
\text { (MT089975) }\end{array}$ & $491 / 495(99 \%)$ & LC638666 \\
\hline $\mathrm{H} 25$ & $\begin{array}{c}\text { Talaromyces pinophilus } \\
\text { (MT730086) }\end{array}$ & $503 / 503(100 \%)$ & LC638667 \\
\hline
\end{tabular}


Table 1. Cont.

\begin{tabular}{|c|c|c|c|}
\hline \multicolumn{4}{|c|}{ (b) } \\
\hline $\begin{array}{l}\text { Non-Leguminous } \\
\text { Soil }\end{array}$ & $\begin{array}{c}\text { BLAST Closest } \\
\text { Match }\end{array}$ & Identity & Accession Number \\
\hline B1 & $\begin{array}{l}\text { Purpureocillium } \\
\text { lilacinum } \\
\text { (MW113495) }\end{array}$ & $541 / 541(100 \%)$ & LC638626 \\
\hline B2 & $\begin{array}{l}\text { Stachybotrys sp. } \\
\text { (KC305351) }\end{array}$ & $501 / 501(100 \%)$ & LC638627 \\
\hline B3 & $\begin{array}{l}\text { Mucor sp. } \\
\text { (MW789351) }\end{array}$ & $568 / 568(100 \%)$ & LC638628 \\
\hline $\mathrm{B} 4$ & $\begin{array}{l}\text { Taifanglania sp. } \\
\text { (KP143091) }\end{array}$ & $468 / 473(98 \%)$ & LC638629 \\
\hline B5 & $\begin{array}{l}\text { Mucor circinelloides } \\
\text { (JN226939) }\end{array}$ & $571 / 572(99 \%)$ & LC638630 \\
\hline B6 & $\begin{array}{l}\text { Trichoderma harzianum } \\
\text { (MK594269) }\end{array}$ & $531 / 531(100 \%)$ & LC638631 \\
\hline B7 & $\begin{array}{c}\text { Mucor circinelloides } f . \\
\text { circinelloides } \\
\text { (AY243943) }\end{array}$ & $558 / 563(99 \%)$ & LC638632 \\
\hline B8 & $\begin{array}{l}\text { Humicola fuscoatra } \\
\text { (KY310738) }\end{array}$ & $489 / 490$ (99\%) & LC638633 \\
\hline B9 & $\begin{array}{c}\text { Trichoderma harzianum } \\
\text { (MT090002) }\end{array}$ & $552 / 552(100 \%)$ & LC638634 \\
\hline B10 & $\begin{array}{l}\text { Aspergillus niger } \\
\text { (MW931861) }\end{array}$ & $517 / 517(100 \%)$ & LC638635 \\
\hline B11 & $\begin{array}{l}\text { Mucor circinelloides } \\
\text { (MW763155) }\end{array}$ & $549 / 550(99 \%)$ & LC638636 \\
\hline B12 & $\begin{array}{l}\text { Fusarium verticillioides } \\
\text { (MN088603) }\end{array}$ & $482 / 482(100 \%)$ & LC638637 \\
\hline B13 & $\begin{array}{l}\text { Monocillium mucidum } \\
\text { (MH859551) }\end{array}$ & $519 / 519(100 \%)$ & LC638638 \\
\hline B14 & $\begin{array}{c}\text { Stachybotrys } \\
\text { sansevieriae voucher } \\
\text { (KY587783) }\end{array}$ & 499/500 (99\%) & LC638639 \\
\hline B15 & $\begin{array}{l}\text { Humicola grisea } \\
\text { (KF876826) }\end{array}$ & $486 / 486(100 \%)$ & LC638640 \\
\hline B16 & $\begin{array}{l}\text { Taifanglania sp. } \\
\text { (KP143091) }\end{array}$ & $491 / 491(100 \%)$ & LC638641 \\
\hline B17 & $\begin{array}{l}\text { Mucor circinelloides } \\
\text { (JN226939) }\end{array}$ & $571 / 572(99 \%)$ & LC638642 \\
\hline
\end{tabular}

\subsection{Screening of Plant Growth Promoting Fungi (PGPF)}

\subsubsection{Microcosm Experiment under Axenic Conditions}

For PGPF screening, 22 isolates were tested, and fresh root and shoot biomass were measured. Three strains (H1, H2, and H3) from leguminous- and four strains (B1, B4, B6, and B10) from non-leguminous-manure-incorporated soil showed the potential for plant growth promotion (Figure S1). The seven isolates (H1, H2, H3, B1, B4, B6, and B10) were estimated to be closely related to Penicillium brasilianum (KY701767), Clonostachys rosea (KY810798), Trichoderma harzianum (KY552264), Purpureocillium lilacinum (MW113495), Taifanglania sp. (KP143091), Trichoderma harzianum (MK594269), and Aspergillus niger (MW931861), respectively. Phylogenetic analyses of PGPF screening isolates are shown in Figure S2.

\subsubsection{Microcosm Experiment under Non-Axenic Conditions}

For larger scale experiments under non-axenic conditions, dry weights of the shoot and root biomass of the plants were monitored, and were found to be significantly affected by different isolates. In B. rapa growth, B6, B4, B10, H3, and B1 were correlated with 
significant growth in terms of shoot and root biomass when compared with the control (CK) (Dunnett's test $p<0.05$ ). In the case of L. sativa growth, B4, B6, and B10 were correlated with significant growth in shoot and root biomass compared to CK. H1, H3, and B1 showed maximum weight of only root biomass compared to CK (Figure 2a,b).

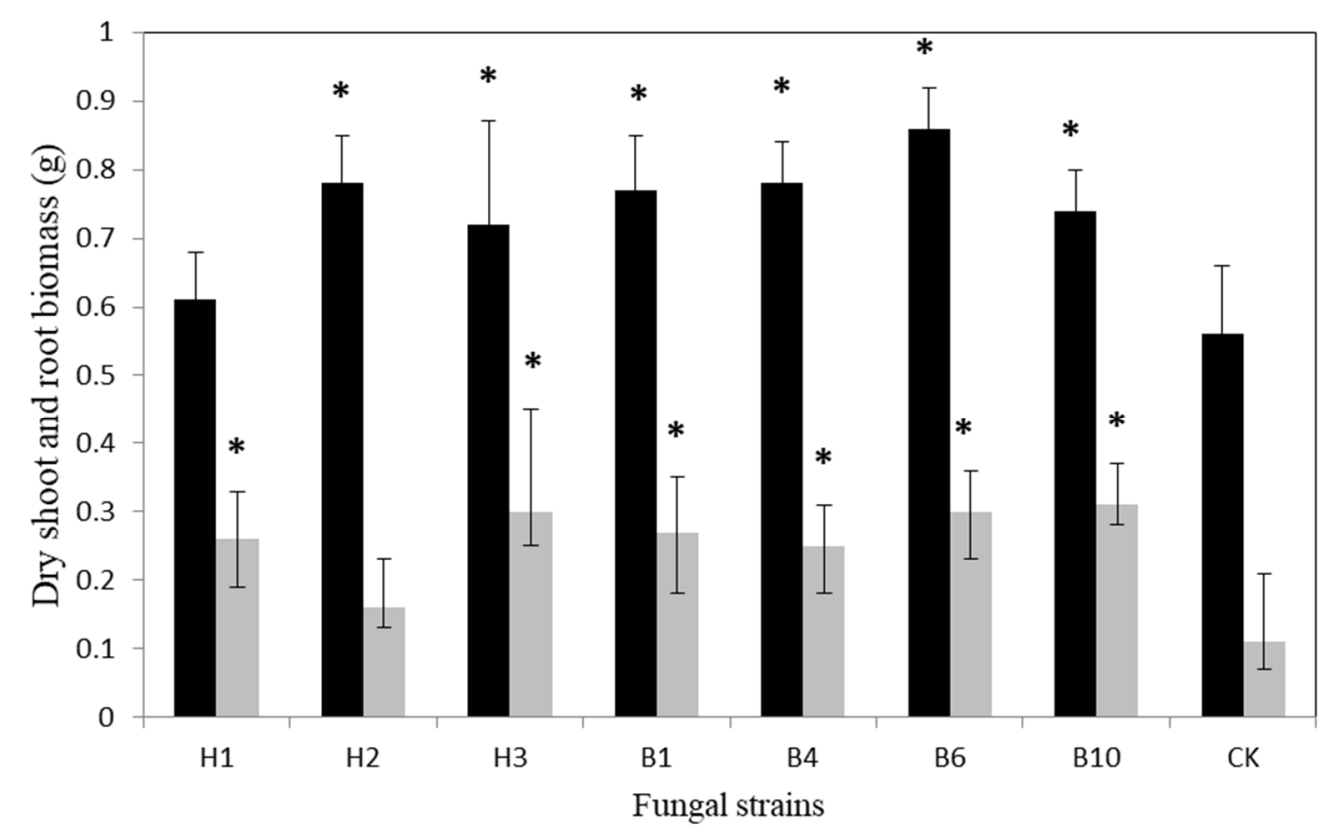

(a)

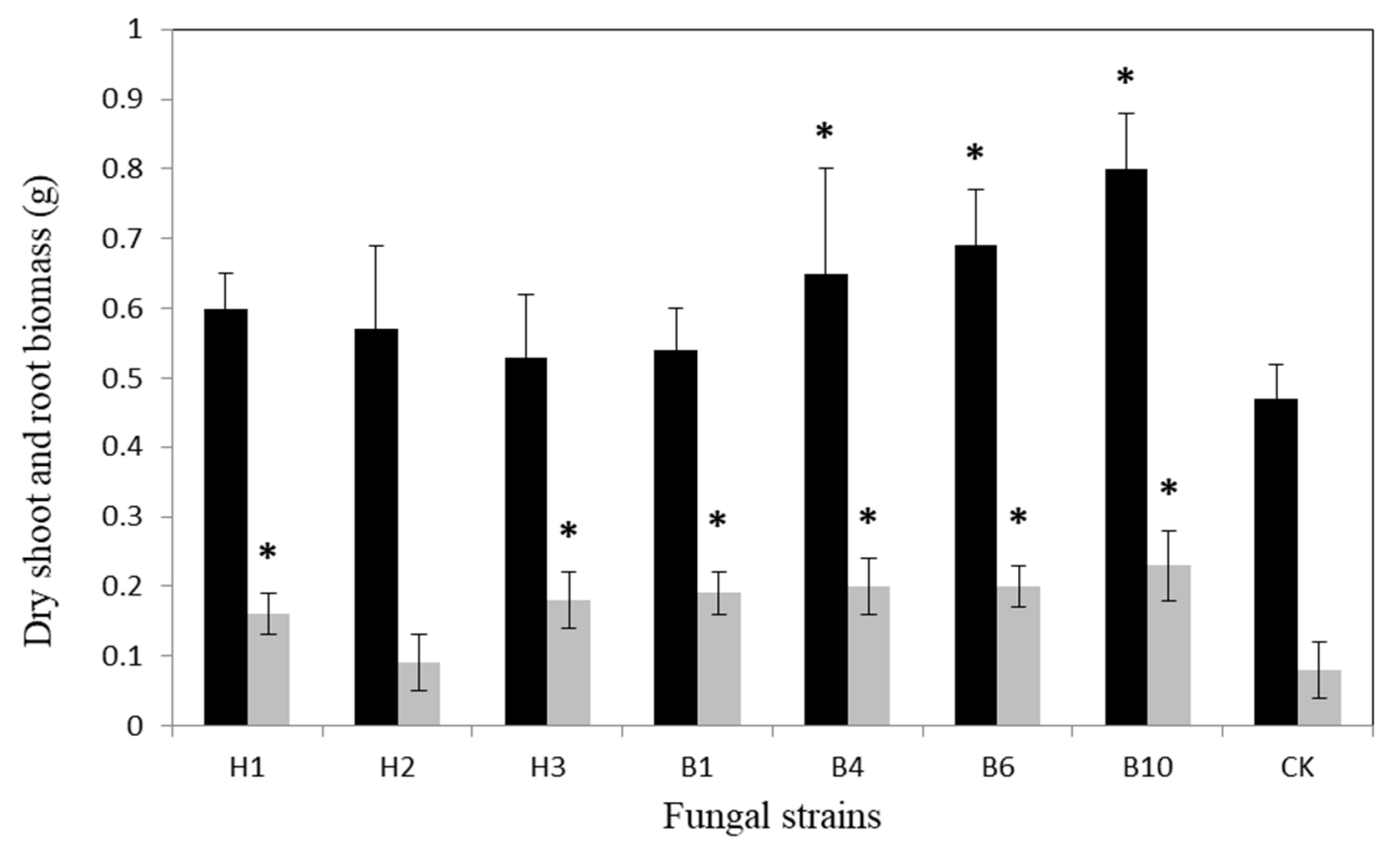

(b)

Figure 2. Experiment with various fungal isolates: Growth response of (a) Brassica rapa and (b) Lactuca sativa in a pot. Black and grey bars show shoot and root biomass, respectively. The error bars show standard deviations between replicates $(n=5)$, where * indicates the statistical significance of the treatment when compared with the control (CK) using Dunnett's test $(p<0.05)$. 


\subsection{Characterization of Selected Strains}

\subsubsection{Plant-Growth-Promoting Traits}

Based on initial screening and the importance of PGP traits for plant growth promotion, phosphate $(\mathrm{P})$ solubilization, siderophore production, and IAA were examined from isolates; the results are provided in Table 2. Strains H1, H2, B1, and B10 showed clear zones on the Pikovskaya agar plates, indicating that these strains have the ability to solubilize P. The siderophore production trend showed that H1, H3, B1, B6, and B10 produce siderophores, as confirmed by the changing color of CAS media; in contrast, none of them showed IAA-like compound production in the presence or absence of tryptophan.

Table 2. Plant-growth-promoting traits, where + indicates possession and-indicates the lack of the trait. Each of the treatments consisted of three biological replicates.

\begin{tabular}{cccccc}
\hline Strain No. & Phosphate Solubilization & Siderophore & IAA & Endoglucanase & $\beta_{\text {-Glucosidase Units }} \mathbf{h}^{-\mathbf{1}}$ \\
\hline H1 & + & + & - & + & $33.19 \pm 1.03$ \\
H2 & + & - & - & + & $27.61 \pm 1.05$ \\
H3 & - & - & - & - & $35.07 \pm 1.65$ \\
B1 & + & + & - & + & $31.89 \pm 0.59$ \\
B4 & - & - & - & + & $27.68 \pm 2.71$ \\
B6 & - & + & - & - & $25.19 \pm 1.05$ \\
B10 & + & + & - & + & $36.83 \pm 1.48$ \\
\hline
\end{tabular}

$\mathrm{H}$ and $\mathrm{B}$ represent hairy vetch and Brassica juncea, respectively.

\subsubsection{Extracellular Enzyme Activities of Isolates}

Enzyme activities of isolates that promote plant growth were examined directly and indirectly by providing nutrients to the soil environment. Among the isolates evaluated, $\mathrm{H} 1$, H2, B1, B4, and B10 showed clear halo zones around the colony growth while assessing for endoglucanase activity (Table 2). Quantification analysis was also carried out to determine the glucosidase activity of the isolates. Glucosidase activity was different among the isolates, and the highest activity was recorded for strain B10 (Table 2).

\section{Discussion}

The fungal structures in the soils incorporated with different green manures were poorly understood. This, to the best of our knowledge, is the first study to determine that certain fungal strains isolated from the soils incorporated with different types of green manure promote plant growth. Although our previous report showed different fungal communities between hairy-vetch- and B. juncea-incorporated soils using non-culturable methods [11], this study also showed that different green manures-such as hairy vetch (leguminous) and B. juncea (non-leguminous) - resulted in different fungal isolation even from the same soil. Notably, we found that the fungal genera Penicillium, Trichoderma, and Talaromyces were higher in abundance in leguminous-manure-incorporated soil; in contrast, Mucor, Taifanglania, and Trichoderma were more abundant in non-leguminous-manureincorporated soil (Figure 1a,b). On the other hand, high-throughput sequencing analysis also showed that the effects of the two green manures were different, with the genera Cryptococcus, Entoloma, Olpidiaster, and Waitea being dominant in B. juncea-incorporated soils, while Coprinellus, Aspergillus, Clonostachys, and Arizonaphlyctis were dominant in hairy-vetch-incorporated soils [11]. Both culturable and non-culturable methods showed different results in our study. In addition, a total of $31.8 \%$ of strains-in which $27 \%$ (3 strains out of 11 strains) and $36 \%$ (4 strains out of 11 strains) of the strains were isolated from the soil incorporated with hairy vetch and B. juncea, respectively-isolated from both incorporated soils showed a plant-growth-promoting effect on $B$. rapa. In contrast, when $L$. sativa plants were used to evaluate plant-growth-promoting ability, fungal strains isolated from $B$. juncea-incorporated soil were more effective for growth promotion than those from hairy-vetch-incorporated soil (Figure 2b). Wang et al. [32] also reported that fungal communities respond differently to the strong influence of different plant species. In our findings, different plant-growth-promoting fungi contributed to the growth of $B$. rapa and 
lettuce. Since each green manure incorporation showed different fungal isolation from the soil, and PGPF also differed depending on the target plant, this indicates the importance of the selection of different types of green manure for each target plant. Generally, the effects of PGPF on plant growth promotion have been directly or indirectly linked to their PGP traits and the mineralization of nutrients, which could be their primary mechanism of action [21]. With regard to PGP traits, four out of seven strains showed P solubilization and siderophore production (Table 2). Interestingly, P solubilization and siderophore production came from common strains within the Penicillium spp. strain H1, Purpureocillium spp. strain B1, and Aspergillus spp. strain B10. In a similar study, Qarni et al. [33] also reported that inoculation with Penicillium spp. improved root growth and increased P uptake, and higher $P$ availability was observed in post-harvest soil samples. Similarly, Aspergillus spp. have the ability to produce siderophores and solubilize $\mathrm{P}$ during qualitative and quantitative analyses [21]. However, to the best of our knowledge, no previous study has reported that Purpureocillium spp. produce siderophores. Generally, siderophore production chelates iron in soils with high $\mathrm{pH}$ to facilitate plant uptake $[4,34]$. In agriculture, siderophores are responsible for enhancing $\mathrm{P}$ availability [35], as they chelate heavy metals and solubilize iron phosphatase, enhancing nutrient uptake for plant growth [36]. Therefore, our results suggest that our isolated strains enhanced the growth of different vegetable crops via $\mathrm{P}$ solubilization and siderophore production in the soil.

The incorporation of different green manures influences enzyme activities produced by the isolated strain. In particular, hairy vetch green manure has a low C/N ratio (11.7) that decomposes quickly, resulting in high and rapid nutrient mineralization through microbiological activities [13]. In this study, fungal abundance was higher in hairy-vetch-incorporated soil than in B. juncea-incorporated soil, and strains H1, H3, B6, and B10 produced more $\beta$-glucosidase than other isolates (Table 2). Purahong et al. [37] and Carson et al. [38] reported that enzymes produced by fungi can decompose and mobilize plant residues, and can boost the nutrients via decomposition of soil organic matter. Our results showed that incorporating green manure increased fungal biomass and enzyme activity, meaning an increase in the release of nutrients for plants. Hairy vetch green manure, in particular, might be quite effective in promoting plant growth by providing nutrient sources and decomposition of organic matter by increasing fungal biomass. Liu et al. [39] reported that soil organic carbon and nutrients were the primary drivers of soil fungal community structure and composition. Other studies have also shown that the application of microbes increases the availability of substrates with microbial growth, leading to the enhancement of enzyme activities compared to without microbial application $[40,41]$.

$B$. juncea is a typical biofumigation crop that is rich in allyl glucosiolate, much as Limnanthes alba Hartw. ex Benth produces $\beta$-glucosidase, and it has been reported to have herbicidal and fertilizer properties $[42,43]$. Limnanthes alba seed meal increases glucosinolate in much the same way as $\beta$-glucosidase increased when Brassica juncea was incorporated into the soil as compared to the control soil in our previously published study [11]. In this study, our isolated strains from Brassica-juncea-incorporated soil also showed the potential for production of $\beta$-glucosidase. In addition, allyl isothiocyanates also have fungicidal and nematicidal properties [44], and Hollister et al. [45] reported that the incorporation of brassicaceous and non-brassicaceous oilseed meal contributes organic matter and isothiocyanates, and land use has the potential to alter the soil microbial community structure. Allyl isothiocyanates could change the microbial community, which could suppress fungal disease [46], but these phenomena might be changed by the soil types and organic materials input into the soil. In addition, fungal sensitivity to allyl isothiocyanates should be considered; for example, Gaeumannomyces spp. were the most sensitive, Rhizoctonia spp. and Fusarium spp. were intermediate, and Bipolaris spp. and Pythium spp. were the least sensitive [47]. Yim et al. [48] also reported that biofumigation crops have more substantial effects on the soil fungal biomass/population with respect to the suppression of fungal diseases. Our results were consistent with their observation that the fungal community differed from that of hairy-vetch-incorporated soil, and fungal biomass was also lower than 
that of B. juncea-incorporated soil (Table S1). However, enzyme activities were maintained in isolated strains compared with those in the hairy-vetch-incorporated soil (Table 2). Since isolated strains from $B$. juncea-incorporated soil may be resistant to biofumigation, and could promote plant growth, it may be used in soils where soil diseases occur and it is difficult to supply organic matter.

\section{Conclusions}

In conclusion, the present study showed the isolation, identification, and characterization of plant-growth-promoting fungi from hairy-vetch- and B. juncea-incorporated soil. Based on our findings, the incorporation of the two green manures showed different fungal communities. The application of fungi isolated from green-manure-incorporated soils could stimulate plant growth promotion, including root growth and development. Although there are limitations to this study, our results indicate that different types of green manure are associated with varied impacts on soil fungal communities and PGPF. This indicates the potential benefits of promoting green manure incorporation in soil.

Supplementary Materials: The following supporting information can be downloaded at https:// www.mdpi.com/article/10.3390/agronomy12020323/s1: Figure S1: Pre-screening of fungal isolates: Growth response of (a) Brassica rapa with leguminous isolates, (b) Lactuca sativa with leguminous isolates, (c) Brassica rapa with non-leguminous isolates, and (d) Lactuca sativa with non-leguminous isolates. This time only one replication was used. Black and grey bars show shoot and root biomass, respectively; Figure S2: Phylogenetic tree of fungal isolates based on ITS rRNA gene sequences showing the evolutionary positions of (a) H1, (b) H2, (c) H3, (d) B1, (e) B4, (f) B6, and (g) B10. Metarhizium marquandii for B1, Diaporthe viticola for B4, Nectria eustromatica for B6, Penicillium viticola for B10, Talaromyces funiculosus for $\mathrm{H} 1$, Stanjemonium ochroroseum for $\mathrm{H} 2$, and Nectria eustromatica for H3 were used as the outgroup. The phylogenetic tree and branching pattern were generated by a neighbor-joining method through the MEGA program; Table S1: Effects of green manure treatments on fungal biomass.

Author Contributions: Conceptualization, R.K.; methodology, R.K. and W.A.; writing-original draft preparation, R.K. and W.A.; writing-review and editing, R.K.; visualization, R.K., supervision, R.K.; project administration, R.K.; funding acquisition, R.K. All authors have read and agreed to the published version of the manuscript.

Funding: This study was supported by Nippon Life Insurance Foundation.

Institutional Review Board Statement: Not applicable.

Informed Consent Statement: Not applicable.

Data Availability Statement: All data generated or analyzed during this study are included in this published article. In addition, sequencing data were deposited to DNA Data Bank of Japan (DDBJ).

Conflicts of Interest: The authors declare no conflict of interest.

\section{References}

1. Mahmood, A.; Iguchi, R.; Kataoka, R. Multifunctional food waste fertilizer having the capability of Fusarium-growth inhibition and phosphate solubility: A new horizon of food waste recycle using microorganisms. Waste Manag. 2019, 94, 77-84. [CrossRef]

2. Babu, A.G.; Kim, S.W.; Yadav, D.R.; Hyum, U.; Adhikari, M.; Lee, Y.S. Penicillium menonorum: A Novel Fungus to Promote Growth and Nutrient Management in Cucumber Plants. Mycobiology 2015, 43, 49-56. [CrossRef]

3. Majeed, A.; Abbasi, M.K.; Hameed, S.; Imran, A.; Rahim, N. Isolation and characterization of plant growth-promoting rhizobacteria from wheat rhizosphere and their effect on plant growth promotion. Front. Microbiol. 2015, 6, 198. [CrossRef]

4. Asghar, W.; Kondo, S.; Iguchi, R.; Mahmood, A.; Kataoka, R. Agricultural Utilization of Unused Resources: Liquid Food Waste Material as a New Source of Plant Growth-Promoting Microbes. Agronomy 2020, 10, 954. [CrossRef]

5. Sinha, R.K.; Herat, S.; Bharambe, G.; Patil, S.; Bapat, P.; Chauhan, K.; Valani, D. Human waste-apotential resource: Converting trash into treasure by embracing the 5 r's philosophy for safe and sustainable waste management. Environ. Res. J. $2009,3,143$.

6. Bowles, T.M.; Acosta-Martínez, V.; Calderón, F.; Jackson, L.E. Soil enzyme activities, microbial communities, and carbon and nitrogen availability in organic agroecosystems across an intensively-managed agricultural landscape. Soil Biol. Biochem. 2014, 68, 252-262. [CrossRef] 
7. Hai-Ming, T.; Xiao-Ping, X.; Wen-Guang, T.; Ye-Chun, L.; Ke, W.; Guang-Li, Y. Effects of winter cover crops residue returning on soil enzyme activities and soil microbial community in double-cropping rice fields. PLoS ONE 2014, 9, e100443. [CrossRef]

8. Zhang, X.; Zhang, R.; Gao, J.; Wang, X.; Fan, F.; Ma, X.; Yin, H.; Zhang, C.; Feng, K.; Deng, Y. Thirty-one years of rice-rice-green manure rotations shape the rhizosphere microbial community and enrich beneficial bacteria. Soil Biol. Biochem. 2017, 104, 208-217. [CrossRef]

9. Brennan, E.B.; Acosta-Martinez, V. Cover cropping frequency is the main driver of soil microbial changes during six years of organic vegetable production. Soil Biol. Biochem. 2017, 109, 188-204. [CrossRef]

10. Chavarria, D.N.; Verdenelli, R.A.; Serri, D.L.; Restovich, S.B.; Andriulo, A.E.; Meriles, J.M.; Vargas-Gil, S. Effect of cover crops on microbial community structure and related enzyme activities and macronutrient availability. Eur. J. Soil Biol. 2016, 76, 74-82. [CrossRef]

11. Asghar, W.; Kataoka, R. Green manure incorporation accelerates enzyme activity, plant growth, and changes in the fungal community of soil. Arch. Microbiol. 2022, 204, 1-10. [CrossRef] [PubMed]

12. Mbuthia, L.W.; Acosta-Martínez, V.; DeBruyn, J.; Schaeffer, S.; Tyler, D.; Odoi, E.; Mpheshea, M.; Walker, F.; Eash, N. Long term tillage, cover crop, and fertilization effects on microbial community structure, activity: Implications for soil quality. Soil Biol. Biochem. 2015, 89, 24-34. [CrossRef]

13. Khan, M.I.; Gwon, H.S.; Alam, M.A.; Song, H.J.; Das, S.; Kim, P.J. Short term effects of different green manure amendments on the composition of main microbial groups and microbial activity of a submerged rice cropping system. Appl. Soil Ecol. 2020, 147, 103400. [CrossRef]

14. Bardgett, R.D.; Van Der Putten, W.H. Belowground biodiversity and ecosystem functioning. Nature 2014, 515, 505-511. [CrossRef]

15. Wang, J.; Li, R.; Zhang, H.; Wei, G.; Li, Z. Beneficial bacteria activate nutrients and promote wheat growth under conditions of reduced fertilizer application. BMC Microbiol. 2020, 20, 1-12. [CrossRef] [PubMed]

16. Turbat, A.; Rakk, D.; Vigneshwari, A.; Kocsubé, S.; Thu, H.; Szepesi, Á.; Bakacsy, L.; Škrbić, B.D.; Jigjiddorj, E.-A.; Vágvölgyi, C. Characterization of the Plant Growth-Promoting Activities of Endophytic Fungi Isolated from Sophora flavescens. Microorganisms 2020, 8, 683. [CrossRef]

17. Khan, N.; Bano, A.; Rahman, M.A.; Guo, J.; Kang, Z.; Babar, M.A. Comparative physiological and metabolic analysis reveals a complex mechanism involved in drought tolerance in chickpea (Cicer arietinum L.) induced by PGPR and PGRs. Sci. Rep. 2019, 9 1-19. [CrossRef]

18. Hossain, M.M.; Sultana, F. Application and mechanisms of plant growth promoting fungi (PGPF) for phytostimulation. Org. Agric. 2020, 1-31. [CrossRef]

19. Naziya, B.; Murali, M.; Amruthesh, K.N. Plant growth-promoting fungi (PGPF) instigate plant growth and induce disease resistance in Capsicum annuum L. upon infection with Colletotrichum capsici (Syd.) Butler \& Bisby. Biomolecules 2020, 10, 41.

20. Mahdi, I.; Fahsi, N.; Hafidi, M.; Allaoui, A.; Biskri, L. Plant Growth Enhancement using Rhizospheric Halotolerant Phosphate Solubilizing Bacterium Bacillus licheniformis QA1 and Enterobacter asburiae QF11 Isolated from Chenopodium quinoa Willd. Microorganisms 2020, 8, 948. [CrossRef]

21. Galeano, R.M.S.; Franco, D.G.; Chaves, P.O.; Giannesi, G.C.; Masui, D.C.; Ruller, R.; Corrêa, B.O.; da Silva Brasil, M.; Zanoelo, F.F. Plant growth promoting potential of endophytic Aspergillus niger 9-p isolated from native forage grass in Pantanal of Nhecolândia region, Brazil. Rhizosphere 2021, 18, 100332. [CrossRef]

22. Zhang, Y.; Chen, F.-S.; Wu, X.-Q.; Luan, F.-G.; Zhang, L.-P.; Fang, X.-M.; Wan, S.-Z.; Hu, X.-F.; Ye, J.-R. Isolation and characterization of two phosphate-solubilizing fungi from rhizosphere soil of moso bamboo and their functional capacities when exposed to different phosphorus sources and $\mathrm{pH}$ environments. PLoS ONE 2018, 13, e0199625. [CrossRef] [PubMed]

23. Martin, J.P. Use of acid, rose bengal, and streptomycin in the plate method for estimating soil fungi. Soil Sci. 1950, 69, 215-232. [CrossRef]

24. Kumar, S.; Stecher, G.; Li, M.; Knyaz, C.; Tamura, K. MEGA X: Molecular evolutionary genetics analysis across computing platforms. Mol. Biol. 2018, 35, 1547-1549. [CrossRef] [PubMed]

25. Pikovskaya, R. Mobilization of phosphorus in soil in connection with vital activity of some microbial species. Mikrobiologiya 1948, $17,362-370$.

26. Schwyn, B.; Neilands, J. Universal chemical assay for the detection and determination of siderophores. Anal. Biochem. 1987, 160, 47-56. [CrossRef]

27. Pérez-Miranda, S.; Cabirol, N.; George-Téllez, R.; Zamudio-Rivera, L.; Fernández, F. O-CAS, a fast and universal method for siderophore detection. J. Microbiol. Methods 2007, 70, 127-131. [CrossRef]

28. Acuña, J.J.; Jorquera, M.A.; Martínez, O.A.; Menezes-Blackburn, D.; Fernández, M.T.; Marschner, P.; Greiner, R.; Mora, M. Indole acetic acid and phytase activity produced by rhizosphere bacilli as affected by $\mathrm{pH}$ and metals. J. Soil Sci. Plant Nutr. 2011, 11, 1-12

29. Shah, S.; Shrestha, R.; Maharjan, S.; Selosse, M.-A.; Pant, B. Isolation and characterization of plant growth-promoting endophytic fungi from the roots of Dendrobium moniliforme. Plants 2019, 8, 5. [CrossRef]

30. Colonia, B.S.O.; Junior, A.C. Screening and detection of extracellular cellulases (endo-and exo-glucanases) secreted by filamentous fungi isolated from soils using rapid tests with chromogenic dyes. Afr. J. Biotechnol. 2014, 13, 52.

31. Asghar, W.; Kataoka, R. Effect of co-application of Trichoderma spp. with organic composts on plant growth enhancement, soil enzymes and fungal community in soil. Arch. Microbiol. 2021, 203, 1-11. [CrossRef] [PubMed] 
32. Wang, Y.; Liu, Y.; Li, J.; Bai, S.; Tian, T. Fungal community composition and diversity in the rhizosphere soils of Argentina (syn. Potentilla) anserina, on the Qinghai Plateau. Fungal Ecol. 2021, 54, 101107. [CrossRef]

33. Qarni, A.; Billah, M.; Hussain, K.; Shah, S.H.; Ahmed, W.; Alam, S.; Sheikh, A.A.; Jafri, L.; Munir, A.; Malik, K.M. Isolation and Characterization of Phosphate Solubilizing Microbes from Rock Phosphate Mines and their Potential Effect for Sustainable Agriculture. Sustainability 2021, 13, 2151. [CrossRef]

34. Khan, A.; Singh, P.; Srivastava, A. Synthesis, nature and utility of universal iron chelator-Siderophore: A review. Microbiol. Res. 2018, 212, 103-111. [CrossRef]

35. Sharma, S.B.; Sayyed, R.Z.; Trivedi, M.H.; Gobi, T.A. Phosphate solubilizing microbes: Sustainable approach for managing phosphorus deficiency in agricultural soils. SpringerPlus 2013, 2, 1-14. [CrossRef]

36. Gontia-Mishra, I.; Sapre, S.; Sharma, A.; Tiwari, S. Alleviation of mercury toxicity in wheat by the interaction of mercury-tolerant plant growth-promoting rhizobacteria. J. Plant Growth Regul. 2016, 35, 1000-1012. [CrossRef]

37. Purahong, W.; Wubet, T.; Lentendu, G.; Schloter, M.; Pecyna, M.J.; Kapturska, D.; Hofrichter, M.; Krüger, D.; Buscot, F. Life in leaf litter: Novel insights into community dynamics of bacteria and fungi during litter decomposition. Mol. Ecol. 2016, 25, 4059-4074. [CrossRef]

38. Carson, C.M.; Jumpponen, A.; Blair, J.M.; Zeglin, L.H. Soil fungal community changes in response to long-term fire cessation and $\mathrm{N}$ fertilization in tallgrass prairie. Fungal Ecol. 2019, 41, 45-55. [CrossRef]

39. Liu, J.; Sui, Y.; Yu, Z.; Shi, Y.; Chu, H.; Jin, J.; Liu, X.; Wang, G. Soil carbon content drives the biogeographical distribution of fungal communities in the black soil zone of northeast China. Soil Biol. Biochem. 2015, 83, 29-39. [CrossRef]

40. Böhme, L.; Böhme, F. Soil microbiological and biochemical properties affected by plant growth and different long-term fertilisation. Eur. J. Soil Biol. 2006, 42, 1-12. [CrossRef]

41. Tang, H.-M.; Xiao, X.-P.; Tang, W.-G.; Li, C.; Wang, K.; Cheng, K.-K.; Sun, G. Dynamic change of soil enzyme activities and soil microbe during rice main growth stages in different long-term fertilizer regimes. J. Pure Appl. Microbiol. 2017, 11, 649-661. [CrossRef]

42. Hanschen, F.S.; Winkelmann, T. Biofumigation for fighting replant disease-A Review. Agronomy 2020, 10, 425. [CrossRef]

43. Intanon, S.; Hulting, A.G.; Myrold, D.D.; Mallory-Smith, C.A. Short-term effects of soil amendment with meadowfoam seed meal on soil microbial composition and function. Appl. Soil Ecol. 2015, 89, 85-92. [CrossRef]

44. Brown, P.D. Control of soil-borne plant pests using glucosinolate-containing plants. Adv. Agron. 1997, 61, 168-231.

45. Hollister, E.B.; Hu, P.; Wang, A.S.; Hons, F.M.; Gentry, T.J. Differential impacts of brassicaceous and nonbrassicaceous oilseed meals on soil bacterial and fungal communities. FEMS Microbiol. Ecol. 2013, 83, 632-641. [CrossRef] [PubMed]

46. Plaszkó, T.; Szúcs, Z.; Vasas, G.; Gonda, S. Effects of glucosinolate-derived isothiocyanates on fungi: A comprehensive review on direct effects, mechanisms, structure-activity relationship data and possible agricultural applications. J. Fungi 2021, 7, 539. [CrossRef]

47. Sarwar, M.; Kirkegaard, J.; Wong, P.; Desmarchelier, J. Biofumigation potential of brassicas. Plant Soil 1998, $201,103-112$. [CrossRef]

48. Yim, B.; Hanschen, F.S.; Wrede, A.; Nitt, H.; Schreiner, M.; Smalla, K.; Winkelmann, T. Effects of biofumigation using Brassica juncea and Raphanus sativus in comparison to disinfection using Basamid on apple plant growth and soil microbial communities at three field sites with replant disease. Plant Soil 2016, 406, 389-408. [CrossRef] 